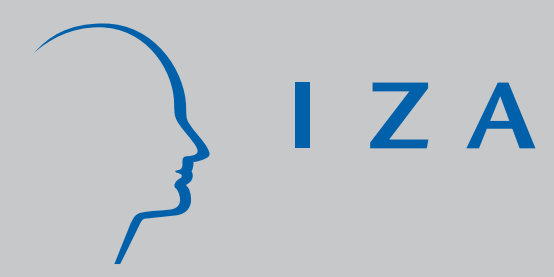

IZA DP No. 1662

Family-Friendly Work Practices in Britain: Availability and Perceived Accessibility

J ohn W. Budd

Karen Mumford

July 2005 


\title{
Family-Friendly Work Practices in Britain: Availability and Perceived Accessibility
}

\author{
John W. Budd \\ University of Minnesota
}

Karen Mumford

University of York

and IZA Bonn

\author{
Discussion Paper No. 1662 \\ July 2005
}

IZA

P.O. Box 7240

53072 Bonn

Germany

Phone: +49-228-3894-0

Fax: +49-228-3894-180

Email: iza@iza.org

\begin{abstract}
Any opinions expressed here are those of the author(s) and not those of the institute. Research disseminated by IZA may include views on policy, but the institute itself takes no institutional policy positions.

The Institute for the Study of Labor (IZA) in Bonn is a local and virtual international research center and a place of communication between science, politics and business. IZA is an independent nonprofit company supported by Deutsche Post World Net. The center is associated with the University of Bonn and offers a stimulating research environment through its research networks, research support, and visitors and doctoral programs. IZA engages in (i) original and internationally competitive research in all fields of labor economics, (ii) development of policy concepts, and (iii) dissemination of research results and concepts to the interested public.
\end{abstract}

IZA Discussion Papers often represent preliminary work and are circulated to encourage discussion. Citation of such a paper should account for its provisional character. A revised version may be available directly from the author. 


\title{
ABSTRACT
}

\section{Family-Friendly Work Practices in Britain: Availability and Perceived Accessibility*}

\begin{abstract}
Using linked data for British workplaces and employees we find a low base rate of workplacelevel availability for five family-friendly work practices - parental leave, paid leave, job sharing, subsidized child care, and working at home - and a substantially lower rate of individual-level perceived accessibility. Our results demonstrate that statistics on workplace availability drastically overstate the extent to which employees perceive that family-friendly are accessible to them personally. British workplaces appear to be responding slowly and perhaps disingenuously to pressures to enhance family-friendly work practices.
\end{abstract}

JEL Classification: $\quad \mathrm{J} 13, \mathrm{~J} 32, \mathrm{~J} 70$

Keywords: family friendly, perceived, access, availability

Corresponding author:

Karen Mumford

Department of Economics and Related Studies

University of York

York YO10 5DD

United Kingdom

Email: kam9@york.ac.uk

\footnotetext{
* The authors acknowledge the Department of Trade and Industry, the Economic and Social Research Council, the Advisory, Conciliation and Arbitration Service, and the Policy Studies Institute as the originators of the 1998 Workplace Employee Relations Survey (WERS98) data, and the Data Archive at the University of Essex as the distributor of the data. The WERS98 data set is publicly available from the Economic and Social Data Service (http://www.esds.ac.uk/). None of these organizations bear any responsibility for the authors' analysis and interpretation of the data.
} 
"Families are the core of our society, but they are under pressure. Women and men struggle with choices over work and family responsibilities...The Government is pledged to support families and children...We want to encourage more family-friendly employment...” (Tony Blair, British Prime Minister, 1998).

\section{Introduction.}

Pressures for the introduction of family-friendly practices in many countries and organizations are coming from a range of directions. In the United Kingdom and United States, for example, changes in the labor supply of women and the greater sharing of household work across parents (Gershuny, 2003) have led to an increased demand for family-friendly work life balance practices from male and female workers across the full socio-economic spectrum. Increasing numbers of elderly people in the population have increased the need for elder care, further strengthening this demand (Department of Trade and Industry, 2004a). The European Union also continues to press Member States to introduce legislation and foster policies which aim to reconcile work and family life; employee advocacy groups lobby for similar legislation at the state and federal level in the United States. These efforts are intended to promote not only gender equality in the workplace but also greater quality care for children and dependents (Caracciolo, 2001).

Moreover, many developed countries have actively linked welfare programmes to working, especially since the latter part of the 1990s (Blank, 2001; Blundell et al., 2000; Blundell and Hoynes, 2004; Elwood, 2000; Meyer \& Rosenbaum, 2001). Questions abound, however, as to whether these welfare-to-work programmes can be effective without strong family-friendly policies in the workplace. The success of a government's anti-poverty programme may be impaired if parents cannot find familyfriendly employment since helping parents to find better jobs through training and search assistance will be of little long term benefit if constraints such as child care issues, flexibility to care for a sick child or attend a parent-teacher meeting, etc, cannot be catered for in the employment relationship (Metcalf, 1990).

As a consequence, the British Government, for example, has adopted a multi-pronged approach to encouraging family-friendly work environments which include the National Childcare Strategy, 
extended maternity and paternity entitlements, the minimum wage, the New Deal for Lone Parents, and the Working Families Tax Credit. The major plank in the Government's programme, however, is the Work-Life Balance campaign. This campaign includes a large scale public awareness component: producing and distributing information to individuals and firms concerning their legal entitlements and/or obligations; ways family-friendly practices can be implemented; and the potential gains from doing so. Perhaps aided by these governmental programmes, firms are increasingly aware of advantages to implementing family-friendly policies, including lowering absenteeism and raising productivity (surveys are provided in Dex \& Scheibl, 1999; DfEE, 2000a; Forth et al., 1996; Gray, 2002; Department of Trade and Industry, 2004b).

It is generally assumed that individual employees also gain from the availability of these policies (Department of Trade and Industry, 2001a). Such gains, however, rest on the extent to which employees use these policies. The central premise of our study is that the link between availability and usage is more complex than is often assumed. First, all workers do not have equal access to such programmes. Studies for the United States reveal that women in high paid managerial and professional employment are more likely to have access to family-friendly policies than are lower paid, lower skilled females (Deitch \& Huffman, 2000). Second, employees are not equally aware of benefit availability. Baird and Reynolds (2004) and Budd and Brey (2003) found significant differences in the awareness of government-mandated family leave entitlements across varying demographic groups of U.S. workers. Third, not all employees with access to family-friendly policies are able to use them. For example, some might not be able to find a suitable co-worker to job share with, others might not be able to afford to work part-time, and others may fear negative reprisals if they take a family leave.

We therefore propose a three-level model in which employee usage depends on perceived accessibility which in turn depends on actual availability. Using data from the 1998 British Workplace Employment Relations Survey (WERS98) we analyze the imperfect nature of the availabilityaccessibility linkage. ${ }^{1}$ WERS98 is a unique survey in which we can link responses of managers and individual workers to similar questions about family-friendly policies for over 2,000 workplaces. We define a family-friendly policy to be 'available' if the manager at the workplace indicates that the 
practice is available to at least some of the employees in that workplace. If individual employees respond that they believe a family-friendly policy is available to them if they needed it, we define them to have 'perceived accessibility.' With these unique data, we are therefore able to analyse two of the three key levels: availability and perceived accessibility. We would also like to be able to consider actual usage of family-friendly practices. Unfortunately, the WERS98 data set does not include direct information on who actually used a family-friendly work practice so analyses of actual usage are left to subsequent research.

Nevertheless, our focus on accessibility is an important advance. Accessibility is an important construct that has not received adequate attention in the previous literature on family-friendly policies. The success of the British Government's anti poverty programme, for example, is likely not dependent on whether managers report that family-friendly policies are available for at least some employees; rather, what seems important is whether parents are actually able to benefit from family-friendly employment. Also, the organizational benefits of family-friendly policies such as reduced turnover and increased productivity are likely to be realized only if individual workers expect to be able to use these policies. Since accessibility is a critical precursor to usage, accessibility is an important construct. In statistical terms, accessibility and availability are key variables of interest in analysing organizational benefits and human resources policies. In this paper we analyse the determinants of the availability of family-friendly practices at the workplace level, and explore perceived accessibility among individual workers within these workplaces. The unique WERS98 data that link workplaces and individual employees allow us to disentangle perceived individual access from workplace availability, and reveal that workplace availability does not guarantee individual access.

\section{Conceptual framework.}

We propose a three-level conceptual framework. At the top level, organizations decide whether or not to offer one or more family-friendly policies to at least some employees. This is the availability level. At the second level, individual employees in workplaces in which family-friendly policies are available may or may not perceive that these policies are accessible to them individually. This is the perceived accessibility level. At the third level, employees who perceive that these policies are 
accessible to them individually choose to use specific policies or not. This is the actual usage level. We focus on the determinants of when family-friendly policies are made available at a workplace level, and more importantly, the level and determinants of perceived accessibility at the individual employee level. Analyses of actual usage is left to other research.

\section{Workplace Availability}

There is a range of alternative explanations available in the literature as to why employers might choose to establish family-friendly practices in their workplaces. For the purposes of the present analysis, it is useful to divide these explanations into three groups or theories: neoclassical economics, internal labor markets, and institutional (or neoinstitutional). These approaches admittedly often overlap in their predictions but they provide a constructive starting point.

The neoclassical economics explanations of employer-provided benefits focus on employer decision-making in spot labor markets. The use of non-pecuniary benefits as a tool to attract employees is well documented in the labor supply literature (Killingsworth, 1983). Economic theory suggests that firms will introduce family-friendly policies if they increase profits either via an increase in performance or by lowering costs. Where the major sources of these cost savings come from being able to offer lower wages, having lower resignation rates, and/or less absenteeism (Department of Trade and Industry, 2001a, page 8, and 2004b; Glass \& Fujimoto, 1995). The firm has a range of non-pecuniary benefits that it can introduce, it might choose to offer family-friendly benefits if it thought that there was a sufficient level of demand amongst its current and potential employees (Guthrie \& Roth, 1999).

For example, in the neoclassical theory, changes such as increases in the labor supply of women and the division of household non-labor market work across parents have led to an increased demand from workers (male and female) for family-friendly practices. Nevertheless, this demand appears to be stronger amongst female employees (Bardoel et al., 1999) and we would expect a significant relationship between workplaces with a large proportion of female employees and the presence of 
family-friendly work practices (Guthrie \& Roth, 1999). It is not clear, however, that women of different occupations and income levels rank the array of possible family-friendly benefits equally (Ingrams \& Simons, 1995; Kelly \& Dobbin, 1999). We would similarly expect married, parents and younger employees to have greater demand. Although age may be non-linear as older workers become responsible for the care of their aging parents (elder care).

We therefore include demographic variables in our analyses to reflect the needs of the employees and their potential demand for work life balance practices. The demographic characteristics included are the gender of the employee; their marital status; age; and the presence of dependent children. We would expect females, those married, parents, and younger and older workers to be positively linked with the presence of family-friendly practices. We incorporate these measures into both the workplace availability analysis using proportions of the workforce in each demographic category..

Internal labor market explanations of employer-provided benefits stem from employers' needs to develop employee commitment. Firms invest in workers and they want workers to invest in firmspecific human capital and have high levels of commitment. Osterman (1995) argues that firms provide non-pecuniary benefits such as family-friendly practices when they face difficulties employing high quality workers into work tasks that require high levels of commitment and non-supervised performance (Doeringer \& Piore, 1971). Empirically, this implies measures of internal labor market and high commitment work systems (such as the presence of training, longer tenure levels, higher general education levels, job ladders, work teams, and employee seniority) will be important.

We include a range of variables to capture these predicted relationships including: current job tenure; the nature of the employment contract (fixed term, temporary or part-time); highest earned education levels; training provision; if working in teams or quality circles; the extent of discretion the employee has over work tasks; and if the wage structure incorporates seniority. We would expect long 
tenured, higher educated and trained employees working in a team environment with discretion over their tasks to be all be positive associated with the presence of family-friendly practices.

In contrast, institutional theories emphasize that organizations respond not only to economic factors, but also to the institutional environment (Guthrie \& Ross, 1999; Kelly \& Dobbin, 1999). In this model, firms are essentially pressured into adopting family-friendly policies by various institutions including trade unions. Unionization of a work group can bring about important changes in the workplace. First, to the extent that the right to strike results in collective bargaining power that is greater than individual, labor's bargaining power will increase. This increased bargaining power might allow unions to negotiate family-friendly policies. Second, union representation can change the nature of workplace decision-making from a neoclassical focus on the marginal employee to a median-voter model with a focus on average preferences (Freeman \& Medoff, 1984). If the average worker has a greater preference for family-friendly policies than the marginal worker, unionized workplaces will have a greater frequency of family-friendly policies. We include measures of trade unionism (if the employee is a current union member and if there is a trade union recognised in the bargaining process in the workplace); and if the workplace has a human resources representative employee in our empirical analysis. We would expect both of these measures to be positively associated with family-friendly work practices.

\section{Perceived Accessibility}

Studies that tout high levels of family-friendly policy availability based on workplace-level measures implicitly assume that individual accessibility is equally high. But individual employees in workplaces with available family-friendly policies might not report that these policies are accessible to them individually for several reasons. First, organizations might offer certain benefits only to specific groups of employees. In other words, there might be imperfect or uneven coverage within a workplace. Second, employees might not be aware of the benefits to which they are entitled. In other words, employee ignorance might be important. And third, employees might feel that a policy is not accessible because of 
various barriers such as financial constraints, impracticalities (such as job requirements preventing telecommuting), and the fear of reprisal or discrimination.

Conceptually, the determinants of uneven coverage within a workplace are analogous to the theories that predict workplace availability. The neoclassical economics theory implies that individual accessibility will depend on labor supply and demand. The internal labor markets theory predicts that accessibility will vary by the need to develop high levels of commitment across different occupations. The institutional framework posits that visible occupations or those with unions will be more likely to have access to family-friendly benefits. As such, the empirical models for individual-level accessibility contain similar explanatory variables to the workplace-level availability models. In the latter, the variables are aggregated to a workplace level (such as the proportion of women in the workplace); in the former, each individual's own characteristics are used (such as whether the employee is male or female).

There are also a number of potential determinants of employee ignorance and barriers to perceiving family-friendly policies as accessible. For example, labor unions may facilitate workers' knowledge and use of existing benefits. Unions can provide information to employees about familyfriendly practices through union newsletters and other communication channels; workshops, training sessions, and representations by shop stewards can help workers perceive benefits as more accessible (Budd \& Mumford, 2004; Budd, 2004). Human resource managers can also disseminate information about policies and protect workers against reprisals from supervisors and co-workers. Job characteristics might underlie structural barriers such as the inability to telecommute. Variables consistent with these explanations are therefore also included in our empirical analyses of perceived availability.

In both the workplace-level availability and individual-level accessibility analyses, there is obviously much overlap across these theoretical approaches and how we can consider the relationships they predict empirically. For example, in the institutional models if firms are to be seen as responding to the needs of their workforce we would expect the demographic variables to also be important, as they 
are in the neoclassical models. Similarly, in the internal labor market models firms are seeking to raise commitment and will be looking to lower resignations and absenteeism. This implies that we cannot separately test the validity of these models within the scope of this paper. We are instead looking for a reasonable set of explanatory variables that can be used as predictors of availability and perceived accessibility. We accordingly also include some control variables such as if the firm is having difficulty filling vacancies in at least two occupations; industry measures; occupation measures; the workplace average wage rate; if the workplace is in the public sector; the size and age of the workplace; and if the firm has multiple workplace sites. We do not have strong prior expectations of the direction of the association these variables may have on the provisions of family-friendly practices.

Whilst we can not provide a set or predicted relationships that is unique to any of these three models (for a more formal approach to testing these models see Wood et al. 2003), we may be able to draw some general conclusions from our analysis. For example, we will be exploring empirically both the availability of family-friendly practices at the workplace level and the perceived accessibility to individual employees. In the neoclassical model it is not clear that there is a difference between these: employees have complete information and can move rapidly to new workplaces, thus firms have an equal incentive to provide the practice at both the workplace and individual level. Similarly, in the internal labor market models, management could reasonably want to use these practices to motivate and maintain their entire workforce. Whilst there may be information problems in the market such that some workplace provision may take the place of signalling, firms still have a strong incentive to make the practices available to many employees. In the institutional models, however, if firms are adopting policies at the workplace level in response to institutional pressures there may be less incentive to provide similar access levels to individual employees; in other words, the provision of family-friendly policies might be more of a public relations campaign than a benefit intended for widespread accessibility. 
Individual Policies or an Index?

Before turning to the data description, there is one remaining conceptual issue-whether to measure family-friendly policies individually or as an aggregate index. There is perhaps a natural tendency to group different types of family-friendly practices together and create an index of availability such that if there were five different practices offered in a workplace the index would range from zero to five. However, family-friendly practices can coexist within workplaces without total coherence to their usage. Differing management types and different workforces may lead to alternative practices being offered.

For example, there are high fixed costs associated with a workplace introducing a nursery whilst the marginal costs fall as the number of employees accessing it rises. In contrast, introducing a job sharing scheme would involve little fixed cost but as the take up rate of the program rises the continuity provided by full time staff members falls and so might the marginal productivity of the whole workforce. We might expect nurseries to be more prevalent in large workplaces and job sharing to be more common in medium sized workplaces. Similarly, availability and perceived accessibility may vary across types of employees. For example, there might be differences related to the task interdependence of various jobs or to employers providing preferential access across different employees.

These possibilities imply that the direction of the impact of the explanatory variables on the availability and perceived accessibility of family-friendly policies in the workplace may not be uniform across all alternative policies. Our analyses are therefore reported separately for each family-friendly policy.

\section{Data.}

The data used in this study are drawn from the British Workplace Employee Relations Survey 1998 (WERS98). WERS98 is the largest, currently available, survey of its type and was conducted between October 1997 and June 1998 (Cully et al., 1998). It is the fourth in an on-going series of 
nationally representative surveys of British workplaces, but is the first to include an employee survey. WERS98 is a rich data source because workplace-level managerial responses can be linked to individual employee-level data. More specifically, interviews for WERS98 were conducted with a manager with day-to-day responsibility for employee relations at 2,191 workplaces and with a formal worker representative at 947 workplaces (all of which had more than 10 employees). Additionally, 25 employees from 1,880 of these workplaces (or all of the employees in workplace with fewer than 25 employees) were randomly selected and asked to complete an employee questionnaire, which resulted in over 28,000 completed questionnaires. The response rates were $80 \%$ for the face-to-face workplace interviews and 64\% for the employee questionnaire. All of these returned surveys are fully linkable to each other.

The linked nature of the WERS98 data enables us to consider a rich variety of information about (a) workplaces that are more likely to offer family-friendly practices to British employees and (b) individuals who respond that they believe a family-friendly practice is accessible to them at their workplace. With these unique data, we are therefore able to analyse two of the three key issues: availability and perceived accessibility. ${ }^{2}$ The workplace-level indicator of each family-friendly policy is derived from the managerial interview. Using the individual-level survey, we then consider the perceptions of workers in only those workplaces where the manager has stated that it is available.

We assume that the manager accurately knows if each family-friendly practice is available in their workplace; in other words, that it is 'an organizational reality.' However, there is no way of knowing the reality of the individual-level responses. The survey measures each individual's perception of whether a family-friendly benefit is accessible to them personally; this is not to say that their expectations will always be realized in practice-some employees who perceive a policy to be accessible might be denied actual usage while some employees who fail to perceive that a policy is accessible might in fact be entitled to use it. Given the data available, it is not possible for us to explore this further, but there is clearly scope for detailed case study analyses to further explore these issues in 
future work.

Table 1 provides descriptive statistics and definitions for the variables used in the study. The data are weighted (in all of the analyses presented in this paper) to allow for both clustering and stratification in the surveying process ${ }^{3}$ and thus represent the British population of workers at workplaces with at least 10 employees.

The measures of family-friendly practices used in this study are:

1. parental leave;

2. working at or from home in normal working hours;

3. job sharing (sharing a full-time job with someone else);

4. paid leave at short notice;

5. workplace nursery or help with the cost of child care.

All of these family-friendly policies were voluntary at the time of the survey. Currently, all pregnant employees are entitled to 26 weeks of paid maternity leave and women who have completed one year of service with their employer are able to take additional unpaid maternity leave. Fathers are entitled to two weeks of paid paternity leave. Male and female employees are also entitled to 18 weeks of unpaid parental leave to be used over the first five years of the child's life. Surveying for WERS98 took place prior to the changes brought in under the Employment Relations Act 1999, when maternity leave entitlement was 14 weeks, with women required to serve two years service in order to qualify for additional maternity leave, and paternity leave was not a statutory entitlement.

WERS98 contains both individual and workplace measures for all five of these family-friendly practices. The main difference in the wording between the individual questions and the workplace questions is that while the individual questions ask whether the policies are available to the individual respondent if needed, the workplace questions ask whether the policies are available to any non- 
managerial employees.

Retaining only those workplaces and individuals where there is complete information for the variables used in the analysis yields 1,565 workplaces. Our first set of workplace-level analyses uses these 1,565 workplaces. For a moment, however, for each of the five family-friendly policies, consider only workplaces in which the interviewed manager responded that the practice is available. Within only these workplaces (which vary from 92 for child care policies to 870 for paid leave policies) in which a policy is available to at least some non-managerial employees, we then identify those individuals indicating that they believe a policy is available to them. As discussed above, we label this individuallevel variable "perceived accessibility.” The mean comparisons of workplace-level availability and individual-level perceived accessibility are shown in Table 2. For example, from the values presented for parental leave in Table 2, we can see that $34.7 \%$ of workplaces offer this practice (or 588 out of the 1565), but out of the 8,584 employees working in these 588 workplaces, only $33.6 \%$ (or 2,884 of the 8,584) say that they believe parental leave is accessible to them personally if needed.

We can see from Table 2 that the workplace availability of family-friendly practices is not widespread. Indeed, of the five family-friendly policies included in the survey, it is only the provision of paid leave that is available at more than half of the workplaces. But of central interest to this paper, it is also not common for employees to believe the practice to be accessible to them, despite the practice actually being available to at least some non-managerial employees in their workplace. With the exception of paid leave, the majority of employees do not believe family-friendly policies would be accessible to them if they needed it. In fact, it is common for two thirds or more of the employees to expect that a given practice would not be provided to them. Furthermore, one in three employees responds that they believe none of these policies are accessible to them. This is a low rate of perceived access across the sampled population.

These differences between the mean rates of perceived accessibility at the individual level and 
availability at the workplace level indicate that workplaces may not provide equal accessibility to all employees, that employee ignorance might be widespread, and/or that significant barriers to accessing family-friendly policies exist . This is supported by the little that we know about actual usage of familyfriendly practices in these workplaces. As noted above, very few employees in workplaces with entitlements to family-friendly practices actually used them: more than a third of managers said no employees had, half of the employers said less that $10 \%$ of the workforce had; and only five percent of managers said that more than a quarter of their workforce had. We will return to this issue in our discussions below.

\section{Availability at the workplace.}

We begin by considering the probable availability of family-friendly practices at the workplace by implementing probit analyses for each of our five measures and using the fully weighted data set. ${ }^{3}$ The results are presented in columns 1 to 5 of Table 3 . The overall test of the explanatory power of the regressors is clearly significant for all the regressions (as is revealed by the Wald joint significance test results reported in the penultimate row) and are comparable with those found in other studies using this and similar data sets (Millward et al, 2001; Almeida-Santos and Mumford, 2004). Overall, the estimates are generally well defined and of the expected sign.

The estimated marginal effect (or differential effects for binary variables) is reported in Table 3. Evaluating variables at their sample means, the marginal effects are calculated as the change in the probability for a small change in the independent continuous variable (or for a discrete one unit change in the binary, dummy, variables). For example, in the first row of results, a small increase in the average current job tenure of the workforce would result in a 0.040 percentage point increase in the probability of paid leave being available. The mean value for the probability of paid leave being available across the workplaces is 0.556 (third from final row of Table 3), so this probability would rise to 0.596 (0.556 plus 0.040 ), or a rise of $7 \%$ ( 0.040 divided by 0.556 ). The calculation is similar for the dummy (or binary) variables. For example, workforces with at least 500 employees are 0.105 percentage points less likely 
to report that parental leave is available, and relative to the weighted sample mean of 0.347 , this point estimate implies a decrease of 30\% (0.105 divided by 0.347$)$. We now consider the results in more detail.

Panel one of Table 3 provides a series of variables describing the characteristics of the workforce in the workplace. We can see that workplaces with longer tenured workforces are significantly more likely to have paid leave and subsidized childcare available, whilst workplaces with a higher proportion of employees on fixed term contracts are less likely to provide a job sharing scheme.

If we concentrate on those variables with a significant impact on two or more of the five measures of availability, we find that the variables impacting the most often on the availability of family-friendly policies are: the average current job tenure of the workforce; the proportion of the workforce part-time or on temporary contracts; the proportion of the workforce educated past secondary school; the proportion of the workforce female; the proportion of the workforce with children; workplaces with at least 500 employees; workplaces that reward ability; the proportion of the workforce in quality circles; the proportion of the workforce that has a lot of discretion over work tasks; workplaces with a recognized union(s); and workplaces with a human resources employee.

The direction of the impact of the explanatory variables on the availability of family-friendly policies in the workplace is not always uniform across all five measures. This is to be expected given our earlier discussion of the different possible classification of these practices and also because the nature of the costs in provided these practices differs greatly.

In terms of the theories presented above, there is only modest support for each of them. For the neoclassical theory, which predicts that family-friendly policies reflect labor market supply and demand pressures, the demographic variables, especially fraction female, are significant in several of the models. The difficulty filling vacancy variable intended to capture labor market tightness, however, is not a 
strong predictor of these family-friendly policies. Nor is there any apparent cost saving through lower wages. For the internal labor market theory, the presence of quality circles increases the likelihood of offering parental leave. On the other hand, workplaces that provide employees with a lot of discretion are less likely to have paid leave and job sharing policies, which does not support the internal labor market explanation. Nor is there a significant relationship found with availability and workplaces that reward seniority. Lastly, however, union representation and the presence of a human resources representative are both positively associated with several of the policies, which is consistent with the institutional theory.

\section{The perceived accessibility of family-friendly policies.}

Analyses in the previous section have revealed characteristics associated with a workplace making family-friendly policies available to non-managerial employees. However, we know from the earlier discussion of the Table 2 results that a substantial proportion of employees in workplaces where a policy is available to some, do not respond that they believe practice is accessible to them personally. We explore the determinants of perceived accessibility by implementing probit analyses for each of our five measures of the perceived accessibility of family-friendly practices for non-managerial individuals who are employed in workplaces where that family-friendly policy is available as reported by the manager in the workplace interview (again using the fully weighted data set). The results are presented in columns 1 to 5 of Table 4.

We have restricted the sample to non-managerial employees since the workplace survey questions ask if the practice is available to non-managerial employees. Our regressions include all of the explanatory variables from the workplace regressions in Table 3 as we want to identify characteristics of the individual employee which impact significantly on the probability of perceived accessibility after allowing for the workforce characteristics associated with greater workplace availability. We also consider the possibility of bias in our results due to selectivity (the type of employees who are more likely to be covered may be more likely to choose workplaces with availability, for example, a young professional mother may look for a workplace with a nursery) and found no significant selection effect 
for any of the five measures of family-friendly practices. ${ }^{4}$ Recall that the sample sizes vary across each column in Table 4 because for each policy separately, we limit the analyses to employees in those workplaces where the manager responded that the policy was available to at least some non-managerial employees.

If we concentrate on those variables with a significant impact on two or more of the five measures of perceived accessibility, we find that the characteristics of the individual that are associated with perceived accessibility are: being female; coupled (living with spouse or partner); having dependent children; higher education levels; working longer hours; longer current job tenure; permanent employment; and current union membership. These results imply that perceived accessibility is not random. Note though, that the direction of the relationships is again not always the same. Females are more likely to believe parental leave, subsidised childcare and job sharing are accessible. They are less likely to believe that paid leave and home working are accessible.

We could expect that the results presented in columns 1 to 5 of Table 4 would not be uniform (such as is the case for females) given our previous discussions of classifications and relative costs. Employee characteristics associated with alternative family-friendly practices vary across these very different types of policies. For examples, employees who are regularly required to interface with customers will it difficult to combine home working with their work tasks.

It can be cumbersome to make sense of a large number of explanatory variables, nevertheless, it is important to emphasize that the number of significant variables in each column in Table 4 imply that there are systematic differences in the level of perceived accessibility across different types of workers. In other words, the pattern of perceived accessibility rates is not random and perceived accessibility is therefore an important construct to add to the research literature on family-friendly policies. This may be seen more clearly in Table 5 where the predicted probability of being perceived accessibility is presented for a range of hypothetical types of employees. 
Comparing panels 1 and 5 of Table 5, we can see that a married, white, 58 year old, father with a post graduate degree, current union membership and working in a professional occupation (panel 5) is substantially more likely to have perceived access across all of the five measures of family-friendly practices than is a single, white, 25 year old mother with CSE education, no union membership and working in personal services (panel 1). He is more than twice as likely to respond that he has parental leave and paid leave access; five times more likely to believe subsidized child care is accessible to him; and more than twenty times more likely to believe he is able to work from home. The hypothetical employee with the lowest levels of perceived accessibility in this example is a single, non-white, male, aged 25, with CSE education, no union membership and working part-time in a workplace with less than 500 employees (panel 3). Such an individual has very little perceived access to parental leave or subsidized childcare and has only slightly higher perceived accessibility than the single mother (panel 1) for paid leave and home working. These results clearly show that perceived accessibility is not equally distributed across employees.

\section{Discussion.}

Our results establish that the concept of perceived accessibility is a meaningful construct: significant numbers of employees in workplaces with entitlements to family friendly policies do not believe they are accessible to them, and these beliefs are not simply random idiosyncrasies. Perceived accessibility should also be a concern for policy and practice. The success of the Government's campaigns to increase the actual take up of family friendly practices in workplaces depends on employees perceiving access, not merely on workplace-level availability. And we hypothesize that the success of human resource management programs to increase firm performance through family friendly policies depends on perceived accessibility, not workplace availability.

While it is beyond the scope of our paper to argue the fairness of the perceived accessibility of family-friendly work practices, our results clearly indicate different perceived access rates for different categories of employees within workplaces. Results presented in Table 5 reveal that those employees 
most likely to be in need of the family-friendly policies are less likely to perceive that they have access to them (single mothers in low paying jobs). Whilst those least likely to need these policies have the highest perceived access (middle age males with high incomes). These results are consistent with Osterman's (1995) argument that family-friendly polices are provided to recruit highly skilled workers; the results are less supportive of the demographic view that the policies are provided in response to the demographic characteristics of the labor force.

Our finding that the factors that significantly impact on both the availability and perceived access to different family-friendly factors vary with the policy being considered further supports this view. It would appear that perceived accessibility varies across types of employees perhaps related to the task interdependence of their job and to their employer providing preferential access across different employees.

It is only by analyzing the linked employee-workplace responses, rather than simply relying on managerial responses as an accurate and uniform indication of policy accessibility for all workers, that these differences become apparent. These issues beg the question as to whether there are institutional avenues for increasing perceived accessibility. Two potential vehicles for increasing the perceived accessibility of family friendly policies are: (i) from organized labor, through the union; and (ii) from the management side, through the human resources representative. Any effect of unionization on perceived accessibility appears to work through membership rather than the presence of a union in the workplace. More specifically, in Table 4, two of the union member estimates are positive and statistically significant while none of the workplace-level union presence estimates are significant.

The presence of a human resources representative in the workplace is associated with higher probable perceived accessibility for paid leave and parental leave. There is, however, no significant further impact on the probable perceived accessibility of subsidized childcare, home working or job sharing suggesting a limited role for human resources employees as conduits for increasing the 
accessibility of these practices within British workplaces. It should be noted, however that Becker et al. (2001), Pfeffer (2005), Wright et al. (1998), and others assert that a high-level, strategic role for HR is more important than lower-level line roles. Unfortunately, we do not have information on the extent of higher-level HR influence in the organization to fully consider this possibility in the context of familyfriendly policies; this would again be a potential area for future work. In sum, given our data constraints, it appears that both unions and human resources professionals can positively enhance levels of perceived accessibility of family friendly policies, but that there may be room for improvement.

\section{Conclusions.}

Problems of balancing work-life conflicts are a major current policy concern in many countries and the active focus of much international research. Recent Government policies to increase the participation of parents in the labor market, the rising propensity for women to play an active role in the labor market, greater sharing of household non-labor market work across parents, and increased need for elder care have led to an increased demand from workers (male and female) for family-friendly work practices. The British Government has recognized the desire, and often the need, these families have for family friendly practices.

We use linked data from the British Workplace Employee Relations Survey 1998 (WERS98) to analyse the availability at workplaces and the accessibility to employees of five major work life balance policies: parental leave, paid family leave, child care subsidies, working at home options, and job sharing options. With the exception of paid leave, the majority of workplaces do not make these practices available to their employees. We find that the variables most often impacting on the availability of family friendly policies at the workplace are: the average current job tenure of the workforce; the proportion of the workforce part-time or on temporary contracts; the proportion of the workforce educated past secondary school; the proportion of the workforce female; the proportion of the workforce with children; workplaces with at least 500 employees; workplaces that reward ability; the proportion of the workforce in quality circles; the proportion of the workforce that has a lot of discretion over work tasks; workplaces with a recognized union(s); and workplaces with a human resources 
employee.

The linked nature of the WERS98 data further allows us to match employee responses on the perceived accessibility of family-friendly policies with workplace level information on provision. We define a worker as perceiving access if they are employed in a workplace where a practice is available and they respond that that practice is available to them if needed. We find substantially lower perceived accessibility than workplace availability for family-friendly policies in Britain. The characteristics of the individual employee that are associated with a greater probability of perceived accessibility are: female; coupled; having dependent children; higher education levels; working longer hours; longer current job tenure; permanent employment; and current union membership. These results imply that accessibility is not random.

It is only by analyzing the linked employee responses, rather than simply relying on managerial responses as an accurate and uniform indication of policy accessibility for all workers, that these differences become apparent. There are various reasons for different accessibility rates for familyfriendly policies among employees. While we are not able to fully isolate the specific reason(s) for differential accessibility rates, our empirical analyses clearly show that differential family-friendly policy accessibility rates are widespread in British workplaces-and by extension probably in other countries as well. Organizational or workplace-level statistics that are publicized by business or political groups therefore significantly overstate the extent to which family-friendly policies are accessible to individual employees. Efforts to monitor compliance with government mandates by relying on organizational and workplace-level availability statistics are suspect. And initiatives by human resources professionals to improve organizational outcomes via family-friendly practices—or studies by researchers to measure these linkage — can be undermined by a lack of perceived accessibility among individual employees. As a result, researchers, policy makers, advocates, and human resources professionals need to pay greater attention to the concept and reality of perceived individual accessibility for family-friendly policies. 


\section{References.}

Almeida-Santos, F. and Mumford, K.A. 2004. "Employee Training in Australia: Evidence from AWIRS" Economic Record, 80, 53-64

Baird, C.L. and Reynolds, J.R. (2004) "Employee Awareness of Family Leave Benefits: The Effects of Family, Work, and Gender” Sociological Quarterly, 45:2, 325-353,

Bardoel, E.A. Moss, S.A. Smyrnios, K. and Tharenou, P. 1999. "Employee Characteristics Associated with the Provision of Work-Family Policies and Programs." International Journal of Manpower, 20(8), 563-576.

Becker, B.B. Huselid, M and Ulrich, D (2001) The HR Scorecard: Linking People, Strategy and Performance. Boston: Harvard Business School Press.

Blair, Tony. Statement by the Prime Minister. May 1998. Retrieved from the DfEE Website www.dfee.gov.uk/childcare/content1.htm on 26/07/00.

Blank, R.M. 2001. "Declining Caseloads/Increased Work: What Can We Conclude About the Effects of Welfare Reform." Economic Policy Review, 7(2), 25-36.

Blundell, R., Duncan, A., McCrae, J. and Meghir, C. 2000. "The Labour Market Impact of the Working Families Tax Credit.” Fiscal Studies, 21(1), 75-103.

Blundell, R. and Hoynes, H. 2004. "Has 'In-Work' Benefit Reform Helped the Labour Market." in Card, D. Blundell, R and Freeman, R (editors). Seeking a Premier Economy. (NBER, Chicago).

Budd, J.W. and Brey, A.M. 2003. "Unions and Family Leave: Early Experience under the Family and Medical Leave Act.” Labor Studies Journal 28(3), 85-105.

Budd, J.W. and Mumford, K. 2003. "The Relative Availability of Work Life Balance Practices to Lone Parents in Britain." Department of Trade and Industry Occasional Paper.

Budd, J.W. and Mumford, K. 2004. "Trade Unions and Family-Friendly Policies in Britain.” Industrial and Labor Relations Review 57(2), 204-222.

Budd , J.W. 2004. "Non-Wage Forms of Compensation." Journal of Labor Research 25(4), 597-622.

Caracciolo, E. 2001. "The Family-Criendly Workplace: The EC position." International Journal of Comparative Labour Law and Industrial Relations, 17(3), 323-344.

Cully, M., A. O’Reilly, N. Millward, J. Forth, S. Woodland, G. Dix, and Bryson, A. 1998. The 1998 Workplace Employee Relations Survey: First Findings. Department of Trade and Industry.

Deaton, A. 1998. The Analysis of Household Surveys. A Microeconometric Approach to Development Policy. Baltimore: John Hopkins University Press.

Deitch, C.H. and Huffman, M.L. 2001. "Family Responsive Benefits and the Two-Tiered Labor Market." in Hertz, R. and Marshall, N. (editors). Working Families: The Transformation of the American Home, Berkeley: University of California Press, pp. 103-130.

DfEE, Department for Education and Employment. 2000a. Work-Life Balance. Retrieved from the DfEE Website www.dfee.gov.uk/work-lifebalance on 26/07/00.

Department of Trade and Industry. 1999. Workplace Employee Relations Survey: Cross-Section, 1998 
(computer file). $4^{\text {th }}$ ed. Colchester: The Data Archive (distributor), 22 December 1999. SN: 3955.

Department of Trade and Industry. 2001a. Work Life Balance: Essential Guide to Work-Life Balance. September.

Department of Trade and Industry. 2004a. Work Life Balance and Flexible Working - the Business Case. December.

Department of Trade and Industry. 2004b. The Work Life Balance Campaign. December.

Dex, S. and Scheibl, F. 1999. "Business Performance and Family-Friendly Policies." Journal of General Management, 24(4), 22-37.

Dex, S. and Scheibl, F. 2001. "Flexible and Family-Friendly Working Arrangements in UK-based SMEs: Business Cases." British Journal of Industrial Relations, 39(3), 411-431.

Dex, S. and Smith, C. 2001a. "Employee’s Access to Family Friendly Policies and Practices: Analysis of the 1998 Workplace Employee Relations Survey." Research Papers in Management Studies, Judge Institute of Management, WP 16/2001.

Dex, S. and Smith, C. 2001b. "Which British Employers have Family Friendly Policies: Analysis of the 1998 Workplace Employee Relations Survey.” Research Papers in Management Studies, Judge Institute of Management, WP 17/2001.

Dex, S. McCullogh, A. and Smith, C. 2002. "Employee's Awareness of Employer's Flexible Working Arrangements." Research Papers in Management Studies, Judge Institute of Management, WP 02/2002.

Doeringer, P. B. and Piore, M.J. 1971. Internal Labor Markets and Manpower Analysis. Boston: D.C.Heath.

Forth, J. Lissenburgh, S. Callender, C and Millward, N. 1996. "Family Friendly Working Arrangements in Britain." Policy Studies Institute Research Report 16.

Freeman, R B., and Medoff., J.L. 1984.What Do Unions Do? New York: Basic Books.

Gershuny, J. 2003."Web-Use and Net-Nerds: A Neo-Functionalist Analysis of the Impact of Information Technology in the Home." Social Forces 82(1), 139-166.

Glass, J. and Fujimoto, T. 1995."Employer Characteristics and the Provision of Family Responsive Policies." Work and Occupations, 22(4), 380-411.

Gray, H. 2002. "Family-Friendly Working: What a Performance! An Analysis of the Relationship Between the Availability of Family-Friendly Policies and Establishment Performance." CEP Discussion Paper, 529.

Greene, W.H. 2001. Econometric Analysis, $4^{\text {th }}$ Edition. Edgewood Cliffs, NJ: Prentice Hall.

Guthrie, D and Roth, L.M. 1999. "The State, Courts and Maternity Policies in US Organizations: Specifying Institutional Arrangements." American Sociological Review, 64, 41-63.

Heckman, J. 1979. 'Sample Selection Bias as a Specification Error.' Econometrica, 47, 153-161. Ingrams, P. and Simons, T. 1995. "Institutional and Resource Dependence Determinants of Responsiveness to Work-Family Issues.” Academy Management Journal, 38(5), 1466-82. 
Kelly, E. and Dobbin, F. 1999. "Civil Rights Law at Work: Sex Discrimination and the Rise of Maternity Leave Policies.” American Journal of Sociology, 105(2), 455-492.

Killingsworth, M. 1983. Labour Supply. Cambridge: Cambridge University Press.

Metcalf, H. (1990) Retaining Women Employees: Measures To Counteract Labour Shortage. IMS Report 190. Brighton: Institute of Manpower Studies.

Meyer, B.D., and Rosenbaum, D. T. 2001. "Welfare, the Earned Income Tax Credit and the Labor Supply of Single Mothers." Quarterly Journal of Economics, 66 (3), 1063-1114.

Millward, N. Woodland, S. Bryson, A. Forth, J. and Kirby, S. 2001. "A Bibliography of Research Based on the British Workplace Industrial Relations Survey Series." Mimeo, National Institute for Economic and Social Research, November.

Osterman, P. 1995. "Work/Family Programs and the Employment Relationship." Administrative Science Quarterly, 40, 681-700.

Pfeffer, J. 2005. “Changing Mental Models: HR's Most Important Task.” Human Resource Management Journal, 44, 123-128.

Purdon, S. and Pickering, K. 2001. "The Use of Sampling Weights in the Analysis of the 1998 Workplace Employee Relations Survey." WERS98 Data Dissemination Service, NIESR, London.

Thompson, C.A., Beauvais, L.L., and Lyness, K.S. 1999. "When Work-Family Benefits are not Enough: the Influence of Work-Family Culture on Benefit Utilization, Oganizational Attachment, and Work-Family Conflict." Journal of Vocational Behavior, 54(3), 392-415.

Wood, S. de Menezes, L. and Lasaosa, A. 2003. "Family-Friendly Management in the UK: Testing Various Perspectives." Industrial Relations, 42(2), 221-250.

Wright, P.M., McMahan, G.C., McCormick, B, and Sherman, W. S. 1998. "Strategy, Core Competence, and HR Involvement as Determinants of HR Effectiveness and Refinery Performance.” Human Resource Management Journal, 37, 17-29. 
Table 1. British Workplace Employee Relations Survey Sample, 1998: Weighted Descriptive Statistics.

\begin{tabular}{|c|c|c|}
\hline Individual variables & $\underline{\text { Mean }}$ & $\begin{array}{l}\text { Standard } \\
\text { Deviation }\end{array}$ \\
\hline Parental leave & 0.268 & 0.443 \\
\hline Home working during normal working hours & 0.089 & 0.285 \\
\hline Job sharing & 0.149 & 0.356 \\
\hline Paid leave & 0.451 & 0.498 \\
\hline Subsidized child care & 0.036 & 0.185 \\
\hline Age & 39.443 & 11.652 \\
\hline Female & 0.482 & 0.500 \\
\hline Living with spouse or partner & 0.698 & 0.459 \\
\hline Any dependent children aged 0-18 & 0.420 & 0.494 \\
\hline Non-white & 0.037 & 0.188 \\
\hline Hours normally worked in a week & 35.771 & 13.438 \\
\hline Current job tenure & 5.340 & 3.626 \\
\hline Part-time & 0.259 & 0.438 \\
\hline Fixed term & 0.029 & 0.168 \\
\hline Temporary & 0.040 & 0.196 \\
\hline Current union member & 0.389 & 0.487 \\
\hline Other education level & 0.259 & 0.438 \\
\hline CSE or equivalent & 0.124 & 0.329 \\
\hline O level or equivalent & 0.267 & 0.442 \\
\hline A level or equivalent & 0.147 & 0.354 \\
\hline Degree or equivalent & 0.153 & 0.360 \\
\hline Postgraduate degree or equivalent & 0.050 & 0.218 \\
\hline Recognized vocational qualification & 0.379 & 0.485 \\
\hline Managers and senior administrators & 0.086 & 0.003 \\
\hline Professionals & 0.124 & 0.329 \\
\hline Associate professional and technical & 0.087 & 0.282 \\
\hline Clerical and secretarial & 0.155 & 0.362 \\
\hline Craft and skilled service & 0.111 & 0.314 \\
\hline Personal and protective services & 0.083 & 0.275 \\
\hline Sales operator, sales assistant & 0.101 & 0.302 \\
\hline Operative and assembly & 0.132 & 0.339 \\
\hline Other occupational group & 0.121 & 0.327 \\
\hline workplace variables & & \\
\hline Parental leave & 0.442 & 0.494 \\
\hline Home working & 0.172 & 0.378 \\
\hline Job sharing & 0.376 & 0.484 \\
\hline Paid leave & 0.615 & 0.487 \\
\hline Subsidized child care & 0.114 & 0.318 \\
\hline
\end{tabular}


Workplace has at least 500 employees

0.206

0.405

Age of the current workplace

38.691

45.219

Workplace is one of multiple workplaces in enterprise

0.751

0.433

Formal training scheme operates in the workplace

0.469

0.364

Proportion of the workforce female

0.483

0.364

Proportion of the workforce part time

0.259

0.280

Proportion of the workforce not-white

0.041

0.089

Workplace average hourly wage

7.235

2.758

Workplace rewards seniority

0.488

0.500

Workplace rewards ability

0.724

0.447

Proportion of workforce in formally designated teams

0.697

0.368

Proportion of non-managerial workforce in quality

0.218

0.311

Workforce has a lot of discretion over work tasks

0.419

Workforce has some discretion over work tasks

0.227

0.497

Recognized union(s) in workplace

0.443

0.490

Workplace has a human resources employee

0.600

0.498

Difficulty filling vacancies in at least two occupations

0.458

0.385

manufacturing

0.245

0.430

electrical

0.006

0.078

construction

0.033

0.179

wholesale

0.155

0.362

hotels

0.044

0.204

transport

0.060

0.238

finance

0.042

0.200

other business

0.082

0.275

public

0.076

0.264

education

0.098

0.297

health

0.331

other

0.035

0.183

number of employees

19,539

number of workplace

1565

Source: Workplace Employee Relations Survey, 1998. The sample means and standard errors are fully weighted to account for the complex survey design. 
Table 2. Availability and perceived accessibility of family friendly work practices.

\begin{tabular}{lccc}
\hline & $\begin{array}{c}\text { Available at } \\
\text { workplace }\end{array}$ & $\begin{array}{c}\text { Number of employees } \\
\text { entitled to access }\end{array}$ & $\begin{array}{c}\text { Perceived accessibility by } \\
\text { employees }\end{array}$ \\
\cline { 3 - 3 } Parental leave & $34.7 \%$ & & \\
Home work & $(588 / 1565)$ & 8,584 & $33.6 \%$ \\
Job share & $12.7 \%$ & 3,414 & $(2884 / 8584)$ \\
Paid leave & $(199 / 1565)$ & & $16.6 \%$ \\
Child care & $28.9 \%$ & 7,940 & $(567 / 3414)$ \\
& $(425 / 1565)$ & & $26.1 \%$ \\
\hline \hline
\end{tabular}

Source: Workplace Employee Relations Survey, 1998. The data are fully weighted to account for the complex survey design. 
Table 3. Probit analyses of family friendly practices availability in workplaces.

(1) Workforce characteristics

Average current job tenure of workforce

Proportion of workforce on fixed terms

Proportion of workforce temporary

Proportion of workforce part time

Average hours worked in week

Proportion of workforce post secondary school

Proportion of workforce vocationally qualified

Clerical and secretarial (fraction)

(2) Workforce demographics

Proportion of workforce female

Proportion of workforce married

Proportion of workforce with children

Proportion of workforce of ethnic origin

Average workforce age

(3) Workplace characteristics

At least 500 employees

Establishment age (years)

Public sector

Firm has multiple work sites

Workplace offers training

Workplace average wage

Workplace rewards seniority

Workplace rewards ability

Workplace proportion in teams

Workplace proportion in quality circles

Workforce has lot of discretion over work tasks

Workforce has some discretion over work tasks

Difficulty filling vacancies in at least two

occupations

Recognized union(s) in workplace

Workplace has a human resources employee

Industry (11)

Region (9)

Mean of the dependent variable

Wald test of joint significance

Number of observations \begin{tabular}{ll}
$\begin{array}{l}\text { Parental } \\
\text { leave }\end{array}$ & $\begin{array}{c}\text { Paid } \\
\text { leave }\end{array}$ \\
\hline$(1)$ & (2)
\end{tabular}

(1)

(2)

Sub.

$\frac{\text { childca }}{(3)}$

Home Job

(4)

sharing

$\begin{array}{ccccc}-0.002 & 0.040^{\star} & 0.002^{\star} & 0.004 & -0.011 \\ -0.119 & 0.143 & 0.009 & -0.052 & -0.556^{\star} \\ -0.358 & 0.038 & -0.047^{\star} & 0.204^{\star} & -0.129 \\ 0.401^{\star} & -0.318^{\star} & -0.029^{\star} & -0.166^{\star} & -0.220 \\ 0.009^{\star} & -0.000 & -0.001^{\star} & 0.001 & -0.007^{\star} \\ -0.226 & 0.333^{\star} & 0.005 & 0.118^{\star} & 0.223^{\star} \\ -0.014 & 0.130 & 0.013 & 0.037 & 0.015 \\ -0.091 & -0.123 & 0.011 & -0.112^{\star} & -0.119\end{array}$

0.151

$-0.046$

$-0.091$

$0.025^{\star}$

$0.147^{\star}$

0.170

$-0.150$

0.023

0.004

$-0.043$

$-0.062$

0.161

$-0.393$

$-0.030^{*}$

$0.120^{*}$

$-0.187^{*}$

0.011

$-0.003$

$0.023^{*}$

$-0.056$

0.252

$-0.002^{*} \quad 0.002$

$-0.000$

\begin{tabular}{|c|c|c|c|c|}
\hline-0.105 & -0.101 & $0.044^{*}$ & 0.026 & $0.158^{\star}$ \\
\hline-0.239 & $-1.833^{*}$ & -0.034 & -0.262 & 0.294 \\
\hline 0.154 & 0.063 & 0.007 & 0.056 & $0.307^{*}$ \\
\hline 0.059 & 0.058 & -0.003 & -0.007 & $0.151^{*}$ \\
\hline 0.109 & 0.091 & 0.007 & 0.011 & 0.027 \\
\hline $0.019 *$ & -0.008 & -0.001 & 0.001 & -0.013 \\
\hline-0.013 & -0.054 & 0.001 & -0.030 & -0.004 \\
\hline 0.044 & 0.061 & $0.011^{*}$ & 0.028 & $0.137^{*}$ \\
\hline 0.076 & -0.022 & 0.001 & 0.000 & 0.026 \\
\hline $0.169 *$ & -0.062 & 0.002 & $0.050^{*}$ & $0.137^{*}$ \\
\hline 0.111 & $-0.146^{*}$ & 0.001 & -0.002 & $-0.099 *$ \\
\hline 0.070 & -0.064 & $0.006^{*}$ & -0.007 & -0.041 \\
\hline 0.063 & 0.067 & -0.003 & 0.003 & -0.016 \\
\hline $0.178^{*}$ & 0.067 & $0.011^{*}$ & -0.014 & $0.102^{\star}$ \\
\hline $0.198^{*}$ & 0.107 & $0.017^{*}$ & $0.060^{*}$ & $0.163^{*}$ \\
\hline Yes* & Yes & Yes $^{*}$ & Yes & Yes* \\
\hline Yes* & Yes & Yes* & Yes* $^{*}$ & Yes \\
\hline 0.347 & 0.556 & 0.059 & 0.127 & 0.289 \\
\hline $5.05^{\star}$ & $3.00^{*}$ & $4.76^{\star}$ & $4.13^{\star}$ & $7.64^{*}$ \\
\hline 1,565 & 1,565 & 1,565 & 1,565 & 1,565 \\
\hline
\end{tabular}

Source: Workplace Employee Relations Survey, 1998. *statistically significant at $95 \%(p<.05)$. Notes: Each entry contains the marginal effect (or differential effect in the case of a binary variable) weighted by sampling weights. The standard errors account for the stratification in the sampling procedure. Industry and region tests are joint tests. 
Table 4. Probit analyses of perceived accessibility for individual employees.

\begin{tabular}{|c|c|c|c|c|c|}
\hline & $\begin{array}{c}\text { Parental } \\
\frac{\text { leave }}{(1)}\end{array}$ & $\begin{array}{l}\text { Paid } \\
\text { leave } \\
(2)\end{array}$ & $\begin{array}{c}\text { Sub. } \\
\text { childcare } \\
\frac{(3)}{}\end{array}$ & $\begin{array}{c}\text { Home } \\
\text { working } \\
\frac{(4)}{}\end{array}$ & $\begin{array}{c}\text { Job } \\
\text { sharing } \\
\frac{(5)}{}\end{array}$ \\
\hline \multicolumn{6}{|l|}{ Individual characteristics } \\
\hline$\overline{\text { Female }}$ & $0.045^{\star}$ & $-0.030 *$ & $0.065^{\star}$ & $-0.025^{\star}$ & $0.081^{*}$ \\
\hline Non-white & $-0.132^{\star}$ & -0.022 & -0.049 & 0.001 & -0.019 \\
\hline Living with spouse or partner & 0.013 & $0.031^{*}$ & -0.069 & $0.027^{*}$ & 0.003 \\
\hline Any children aged 0-18 & $0.076^{*}$ & -0.021 & $0.074^{*}$ & 0.010 & 0.007 \\
\hline Age & 0.006 & $0.012^{*}$ & 0.005 & 0.004 & 0.001 \\
\hline Normal weekly hours worked & 0.004 & $0.019 *$ & 0.003 & $0.008^{*}$ & $0.008 *$ \\
\hline Current job tenure & 0.003 & $0.007^{*}$ & 0.007 & 0.002 & $0.004^{\star}$ \\
\hline Fixed term & -0.045 & $-0.093^{*}$ & -0.035 & 0.010 & $-0.043^{\star}$ \\
\hline Temporary & $-0.074^{*}$ & $-0.227^{*}$ & 0.088 & -0.020 & 0.014 \\
\hline Part-time & -0.063 & -0.021 & -0.019 & 0.051 & 0.037 \\
\hline Current union member & 0.023 & $0.024^{*}$ & $0.036^{\star}$ & -0.023 & 0.026 \\
\hline Recognized vocational training & 0.009 & -0.023 & 0.010 & -0.009 & -0.021 \\
\hline \multicolumn{6}{|l|}{ Education (O level is omitted category) } \\
\hline CSE or equivalent & $-0.093^{*}$ & $0.045^{\star}$ & -0.022 & $-0.055^{\star}$ & $-0.088^{*}$ \\
\hline A level or equivalent & $-0.081^{*}$ & 0.010 & 0.073 & -0.033 & $-0.072^{*}$ \\
\hline Degree or equivalent & 0.013 & $0.049 *$ & -0.005 & 0.027 & 0.020 \\
\hline Postgraduate Degree or equivalent & -0.011 & -0.010 & -0.012 & $0.046^{*}$ & $0.080 *$ \\
\hline Other education level & 0.065 & -0.037 & 0.023 & $0.105^{\star}$ & $0.068^{*}$ \\
\hline Occupation (9) & Yes & Yes & Yes & Yes & Yes \\
\hline Workplace controls & Yes* & Yes* & Yes* & Yes* & Yes* \\
\hline Mean of the dependent variable & 0.336 & 0.515 & 0.199 & 0.166 & 0.261 \\
\hline Wald test of joint significance & $6.64^{\star}$ & $16.46^{*}$ & $5.06^{\star}$ & $6.07^{*}$ & $7.16^{\star}$ \\
\hline Number of observations & 8,584 & 12,761 & 2,412 & 3,414 & 7,940 \\
\hline
\end{tabular}

Source: Workplace Employee Relations Survey, 1998. *statistically significant at 95\% ( $p<.05)$. Notes: Each entry contains the marginal effect (or differential effect in the case of a binary variable) weighted by sampling weights to allow for the complex survey design. These models include all of the explanatory and control variables as in Table 3. The models also include age squared and hours squared. 
Table 5. Predicted probability of perceived accessibility for hypothetical types of employees.

\begin{tabular}{|c|c|c|c|c|c|}
\hline & \multicolumn{5}{|c|}{ Predicted Probability of Accessibility } \\
\hline Hypothetical Profile & $\begin{array}{l}\text { Parental } \\
\text { Leave }\end{array}$ & $\begin{array}{l}\text { Paid } \\
\text { Leave }\end{array}$ & $\begin{array}{l}\text { Subsidized } \\
\text { Child Care }\end{array}$ & $\begin{array}{c}\text { Home } \\
\text { Working }\end{array}$ & $\begin{array}{c}\text { Job } \\
\text { Sharing }\end{array}$ \\
\hline $\begin{array}{l}\text { Female aged } 25 \text {, white, single mother, } \\
\text { CSE education level, not a union } \\
\text { member, in personal services } \\
\text { occupation, working in a firm with less } \\
\text { than } 500 \text { employees. }\end{array}$ & $31 \%$ & $31 \%$ & $10 \%$ & $4 \%$ & $19 \%$ \\
\hline $\begin{array}{l}\text { Middle-aged (45) white married female } \\
\text { with no children, degree qualification, } \\
\text { in a clerical/secretarial occupation, not } \\
\text { a union member, working in a firm with } \\
\text { more than } 500 \text { employees. }\end{array}$ & $39 \%$ & $63 \%$ & $27 \%$ & $35 \%$ & $41 \%$ \\
\hline $\begin{array}{l}\text { Young (25) non-white, CSE education } \\
\text { level, single, part-time, not a union } \\
\text { member, working in a firm with less } \\
\text { than } 500 \text { employees. }\end{array}$ & $5 \%$ & $35 \%$ & $0.7 \%$ & $6 \%$ & $11 \%$ \\
\hline $\begin{array}{l}\text { Middle-aged (45) white male, married } \\
\text { with children, A-level education, in } \\
\text { technical/semi-professional } \\
\text { occupation, union member, working in } \\
\text { a firm with more than } 500 \text { employees. }\end{array}$ & $47 \%$ & $69 \%$ & $27 \%$ & $65 \%$ & $16 \%$ \\
\hline $\begin{array}{l}\text { Older aged (58) white male, married } \\
\text { with children, postgraduate degree, } \\
\text { union member, professional } \\
\text { occupation. }\end{array}$ & $65 \%$ & $76 \%$ & $51 \%$ & $87 \%$ & $26 \%$ \\
\hline
\end{tabular}

Source: Workplace Employee Relations Survey, 1998. Notes: Each entry contains the predicated probability of accessibility given hypothetical individual characteristics and the parameters reported in Table 4. 
${ }^{1}$ Department of Trade and Industry (1999). Workplace Employee Relations Survey:

Cross-Section, 1998 (computer file). $4^{\text {th }}$ ed. Colchester: The Data Archive (distributor), 22

December 1999. SN: 3955. The WERS98 data set is publicly available from the Economic and Social Data Service (http://www.esds.ac.uk/). A listing of papers using WERS98 and/or the earlier waves of this data set is provided in Millward et al. (2001).

${ }^{2}$ As discussed above, we would also like to be able to consider actual usage of family friendly practices. Unfortunately, the WERS98 data set does not include direct information on who actually used a family friendly work practice. Some managers were asked what proportion of their workforce had actually used one of these entitlements in the previous 12 months. The answer is that very few had: more than a third of managers said none, and only five percent of managers said that more than a quarter of their workforce had.

${ }^{3}$ If the family friendly practice is available in workplace $k$, we set the binary indicator $d_{\mathrm{k}}=1$. The probability of the practice $F$ being available is given by $\operatorname{Pr}\left(d_{k}=1\right)=\operatorname{Pr}\left(F_{k}>0\right)=\phi\left(\beta X_{k}\right)$ where $X_{k}$ is a vector of the explanatory variables thought to influence the availability of the practice in the workplace $(k)$ and $\phi$ is the standard normal distribution function (Greene, 2000). We repeat this analysis for the five family friendly practices. The need to weight complex survey sample data, such as WERS98, is discussed in Deaton (1998) and Purdon \& Pickering (2001).

${ }^{4}$ We estimated maximum likelihood probit models allowing for the possibility of this sample selection and did not find a significant effect of selection mechanism on our predicted probabilities for any of the five measures of family friendly work practices (Greene, 2000; Heckman, 1979). 